\title{
Percursos da cidade em João Antônio
}

Júlio Cezar Bastoni da Silva ${ }^{1}$

A escrita malandra de João Antônio revela, para além da clara atenção aos aspectos desprezados da sociedade brasileira - sobretudo de seus tipos sociais marginalizados -, uma visão específica da cidade que deve ser tomada em conta para a efetiva compreensão do espaço em sua obra. Essa visão não se reduz à mera descrição dos ambientes em que esses tipos citados viviam, mas revela, muito mais, uma relação estabelecida entre a cidade e os que dela fazem uso e a enformam, assim, segundo determinadas configurações, valores e posturas. A marginalidade descrita na literatura de João Antônio, portanto, é localizada, de maneira que a própria representação espacial em suas obras é constitutiva do lugar ocupado pelas figuras sociais que retrata.

A cidade, para João Antônio, está além dos ambientes claramente focalizados quando do tratamento desse espaço pela representação. Em seus escritos, a cidade não abarca apenas seus espaços consagrados, aqueles que lhe conferem um tipo de identidade, pois ao autor é preferível, para a caracterização dos tipos e do ambiente urbano, a representação de aspectos desprezados e alheios a espaços consagrados. Os espaços marginais parecem resgatar, assim, certa forma de identidade da cidade, se não mais verdadeira, pelo menos mais reveladora de suas contradições. Para isso, o autor alude, ainda, à maneira como os indivíduos fazem uso dessa cidade e com ela se relacionam.

Este artigo tratará, sobretudo, de uma obra de João Antônio - que mistura de crônica, conto e reportagem, logo, um gênero em suspensão pela sua própria indefinição frente aos cânones literários $-^{2}$ publicada em 1978 e intitulada Ô, Copacabana!. Desde a interjeição de seu título, nota-se uma postura que se quer reveladora de algo, algo que chame a atenção sobre um aspecto da cidade não contemplado nas visões identitárias comuns. Sobretudo, há que considerar que essa postura é interessante, dado que Copacabana, bairro da Zona Sul carioca, é, talvez, um dos bairros mais famosos do mundo e objeto de todo tipo de representação, o que garante sua identidade junto ao público. Objeto da música popular, de vídeos co-

\footnotetext{
${ }^{1}$ Doutorando em Estudos Literários na Universidade Estadual Paulista "Júlio de Mesquita Filho", campus de Araraquara (UNESP-FCLAr). E-mail: juliobastoni@yahoo.com.br

${ }^{2}$ Para uma discussão mais aprofundada do hibridismo entre literatura e jornalismo dos textos joãoantonianos, remetemos a Coração (2009). Ô, Copacabana! é também entendido como um misto de narrativa, reportagem e crônica por Joana D’Arc Ribeiro (2007, p. 39-40).
}

est. lit. bras. contemp., Brasília, n. 42, p. 129-149, jul./dez. 2013 
merciais e de um prestígio sem paralelo, mesmo para uma cidade que é conhecida geralmente por sua beleza natural, o bairro da ex-capital federal guarda em seus meandros aspectos que transcendem essa visão mais consolidada, aspectos estes que lançam luz não apenas sobre a cidade do Rio de Janeiro mas talvez sobre a própria configuração da sociedade brasileira e de suas contradições. O Rio de Janeiro, tal como representado por João Antônio, supera, pois, sua condição de cidade marcada pela beleza natural e pela carnavalização de suas diferenças sociais - o tipo do pobre, do malandro do morro, do sambista e que tais, festejados e despolitizados em sua elevação em nível de identidade citadina ou mesmo nacional -, para mostrar sua faceta mais ou menos obscura, desprezada intencionalmente ou não para efeitos de propaganda e prestígio. Nesse sentido, a representação da cidade em João Antônio busca um critério de totalidade, tanto esclarecendo as possíveis relações estabelecidas entre aquele prestígio e a realidade que se observa em seu cotidiano quanto lançando um possível veio crítico em torno de suas aporias.

\section{A cidade moderna nos trópicos}

$\hat{O}$, Copacabana!, esse conto-reportagem tão atraente quanto indefinível enquanto gênero, estabelece uma imagem da cidade moderna que é de sumo interesse, seja para a compreensão do próprio bairro de Copacabana por um viés subalterno, isto é, identificado às classes populares, seja para pensar as contradições da cidade, da urbanização e, ainda, da própria formação social brasileira em sua modernização perenemente incompleta. $\mathrm{O}$ foco do narrador-repórter-cronista se volta principalmente para os tipos decadentes, excluídos, outsiders da cidade moderna, seus dejetos sociais ostensivamente ocultos pela propaganda e pela ideologia do trabalho. Por outro lado, e em ligação ostensiva com esses tipos sociais, o narrador apresenta os espaços urbanos ignorados pela visão dominante sobre o bairro e a cidade, espaços onde se dá a vida cotidiana, para além das representações contemporizadoras do Estado e do mercado. Aliás, cabe notar que o foco do narrador ao mesmo tempo em que esclarece esses espaços, esclarece também os tipos sociais que nele atuam: a revelação da humanidade de seus personagens desprezados pelas elites, vítimas de uma invisibilidade social marcante, se dá em homologia com a revelação dos aspectos degradados e esquecidos da cidade.

Para falarmos dos percursos de João Antônio na cidade, os escritos de Walter Benjamin sobre a cidade moderna - Paris -, presentes nas Passagens e em Charles Baudelaire: um lírico no auge do capitalismo, nos lançam boas indicações sobre uma forma de abordar a cidade sem que fiquemos 
estreitamente atados ao âmbito das diversas disciplinas, como a geografia, a sociologia ou a crítica literária; a abordagem de Benjamin, ainda, nos permite uma comparação de interesse, qual seja, a relação entre as imagens do progresso e da modernização de uma cidade que se encontra entre as capitais culturais e econômicas do mundo e as de outra, cujo reconhecimento menos vem de sua importância, digamos, político-econômica, que de sua vitalidade cultural e de suas belezas sempre louvadas pela propaganda de viés turístico. Cabe, portanto, relacionar algumas questões lançadas por Benjamin às encontradas no texto e na postura de João Antônio frente à cidade moderna - uma orientação analítica, pois, que pressupõe a dicotomia centro-periferia, considerando ambas as cidades.

É necessário, primeiramente, estabelecer algumas relações, talvez centrais nos textos de João Antônio e Walter Benjamin. Ambos o textos atribuem um papel central a determinados espaços, símbolos do tipo de paisagem citadina e de sua vida social que intentam representar: as passagens, no caso de Benjamin; em João Antônio, a nossa forma mais tradicional, mais próxima desse modelo francês - que historicamente, antes da virada em função do poder econômico norte-americano, sempre fora o nosso modelo de civilização (Ribeiro, 2001, p. 138-139) -, que é a galeria. As passagens parisienses, verdadeiro templo das mercadorias e de um estilo de vida que se modernizava, tendo como referência um incentivo ubíquo ao consumo de massa, são, para Benjamin "o centro das mercadorias de luxo" (2009, p. 40), aliando, para seu aparecimento, a pré-condição não apenas de um florescimento do comércio mas também de um tipo de técnica específica, a construção em ferro. As passagens são, pois, fruto de condições econômicas, tais como a possibilidade técnica, o florescimento comercial e, além disso, a especulação imobiliária - sinais, logo, de um capitalismo em ascensão. Além disso, como nota Benjamin, as passagens são o cenário ideal para o flâneur, sobretudo antes do alargamento das calçadas realizadas pela reforma de Haussmann, durante o Segundo Império (Benjamin, 1989, p. 34-35). O flâneur não é apenas aquele que caminha pela cidade e observa; há que ter em mente que a flânerie supõe uma experiência da cidade, algo como um "saber sentido" (Benjamin, 2009, p. 462).

Em Ô, Copacabana!, tal como afirma Rodrigo Lacerda em prefácio ao livro (Lacerda, 2001, p. 7), quem ocupa papel central na representação do bairro é uma passagem, isto é, uma galeria: a Galeria Alaska. Reduto de boates, bares, restaurantes e do comércio miúdo, além de contar com um prédio de apartamentos em seus níveis superiores, ela se relaciona obliquamente com o modelo francês das passagens, revelando, tal qual sua possível forma matriz, as contradições do capitalismo na cidade moderna: 
no caso brasileiro, as contradições do subdesenvolvimento e suas implicações no espaço urbano. Aqui, por outro lado, o flâneur talvez não seja exatamente um dos frequentadores da galeria. ${ }^{3}$ Estes são variáveis, segundo nosso narrador-repórter: de dia, é galeria "família"; "[à] noite, aqui a coisa muda" (Antônio, 2001, p. 75-76). A "fauna e a flora" da galeria (p. 80) se alteram, e vira espaço de boêmios, pederastas, turistas em busca de suas boates e a "moçada" que sai da Zona Norte e dos subúrbios, iludidos pela máscara de vanguarda das luzes de Copacabana (p. 80).

A imagem da Galeria Alaska não nos deixa de recordar a representação da Passage de l'Opéra presente no texto de Aragon O camponês de Paris, muito apreciado por Benjamin. $\mathrm{O}$ ar de decadência, que aparenta ser comum entre ambas, no entanto, é diverso: na galeria brasileira, não há o que Aragon diz da galeria condenada à demolição para a edificação de um novo boulevard: "santuário dum culto do efêmero, na paisagem fantasmática dos prazeres e das profissões malditas, incompreensíveis hoje e que o amanhã não conhecerá jamais" (Aragon, 1996, p. 44-45). Isso se dá não pela falta das características de decadência na Alaska, mas porque estas parecem ter uma presença imediata, paralela, e não progressiva temporalmente; a convivência entre dois públicos, entre o comércio diurno e o noturno, a chegada da moçada da Zona Norte e dos turistas a serem feitos de trouxas nas boates, lembram uma convivência mais íntima entre a imagem referendada pelas ilusões da sociedade do consumo e a negação dessa própria imagem. A decadência do bairro e da galeria brasileiros se esconde atrás de uma máscara, máscara que "jamais caiu de todo" (Antônio, 2001, p. 80). ${ }^{4}$

Voltando ao flâneur, é necessário dizer que este não se encontra representado pelos personagens que aparecem na obra; ao contrário, a própria

\footnotetext{
${ }^{3}$ Em sua dissertação de mestrado, Silva Neto (2002) compara o andar dos personagens de João Antônio na cidade ao flâneur evocado por Benjamin. As diferenças são significativas: o autor nota que o flâneur, diferentemente dos personagens de João Antônio, possui uma posição social burguesa, o que o habilita a possuir tempo ocioso para o vagar. Além disso, os personagens andejos de João Antônio, invariavelmente pobres ou deslocados socialmente, não possuem aquela espécie de despreocupação interessada na cidade do flâneur baudelariano. Quando se considera o narrador, ao contrário, a forma da descrição encontra uma semelhança bastante grande com a experiência da cidade de que fala Benjamin (Silva Neto, 2002, p. 45-47).

${ }^{4}$ Cabe ressaltar que boa parte do texto que João Antônio dedica à Galeria Alaska em $\hat{O}$, Copacabana! - além de outros trechos sobre a "bandidete" Mariazinha Tiro-a-Esmo - já havia sido publicada em Malhação do Judas carioca (Antônio, 1975b, p. 5-22). Ainda, como nota Hugo Alexandre de Lemos Belluco (2006, p. 99), estes textos e outros, anteriormente publicados no trabalho de João Antônio junto à imprensa, perfazem boa parte do texto de $\hat{O}$, Copacabana!. Este fato não elimina a originalidade da obra, uma narrativa montada, porém una, cuja sustentação está no olhar de minúcia crítica que o andejo narrador dedica ao bairro.
} 
estrutura da obra, na qual esses personagens se encaixam, não parece ter sido tecida senão por um misto de flâneur e boêmio, malandro e andejo, que narra e reporta o bairro. Como diz Rodrigo Lacerda, "João Antônio perambulava - antes um observador no nível da rua que da janela - e essa perambulação errática se reflete no texto, assim como a caótica situação urbana do bairro nele está mimetizada" (Lacerda, 2001, p. 6). Não falta, pois, ao nosso narrador a experiência que é demandada do flâneur junto à cidade; o narrador passeia pelo bairro como passeia pelo texto, representando a própria vivência num cotidiano em que a modernidade não encontrou um assento confortável. $\mathrm{O}$ texto disposto em longos fragmentos se assemelha a flashes captados e interpretados por um narrador acostumado ao andar e refletir sobre a cidade, em possuí-la enquanto objeto de experiência, portanto. Em outras obras do autor, podemos notar o mesmo, seja na representação do Rio de Janeiro seja na de São Paulo e de seus tipos sociais.

Em Malagueta, Perus e Bacanaço (1975a), publicada originalmente em 1963, primeiro livro do autor, o conto que dá título ao livro narra a andança de três, no dizer de João Antônio, "merdunchos", ${ }^{5}$ aspirantes e veteranos da malandragem, da Lapa, passando por vários bairros em busca de mesas de sinuca onde poderiam faturar uns cobres, e de volta a ela. Chamam a atenção os ambientes frequentados, bares e lugares de cuja existência pouco suspeita a classe média da cidade. Trata-se da mesma "massa indefinida", na expressão de Marx citada por Benjamin em "A boêmia", parte de "Paris do Segundo Império" (Benjamin, 1989, p. 10), mas sem os conspiradores políticos que dela fazem parte. A "conspiração" se dá nessa obra de João Antônio pela marginalidade, pelo "lucro em perspectiva", colocado na conta de um "otário" iludido pelo conluio entre os três malandros na sinuca (Antônio, 1975a, p. 117). Nesse conto, os personagens andam, perambulam pela cidade; nas palavras de Jesus Antônio Durigan, é na rua que se dá o aprendizado: "[na] própria busca de sobrevivência que o 'malandro' realiza, perambulando pela cidade grande, sofrendo e aprendendo com os mais velhos, malandros experientes" (Durigan, 1983, p. 216).

\footnotetext{
5 "Merduncho", na própria classificação de João Antônio: "Essa gente ganha um poder dramático, a partir de sua figura física da magreza, da palidez, do envelhecimento precoce. Entende? Não são bem os bandidos, não são bem os marginais, são bem uns pés-de-chinelo, o pé-rapado, o zé-mané, o eira-sem-beira,o merduncho - aqui no Rio, se usa esta expressão merduncho. Quer dizer, é um depreciativo quase afetivo de um merda, merda-merda; então, em vez de um bosta-bosta, o cara diz - "é um merduncho"” (Antônio, 1976, p. 55). Ainda: "tipo que fica muito próximo do marginal, que é o lúmpen, o cara marginalizado mesmo" (Antônio, 1976, p. 53). O interesse demonstrado pelos "merdunchos", pelos marginalizados, nos parece do mesmo sentido do dispensado por Walter Benjamin ao "trapeiro" de Paris: alguém que recolhe, e é ele próprio, uma espécie de escolho da cidade (Benjamin, 1989, p. 15-17).
} 
No entanto, assim como em $\hat{O}$, Copacabana!, a experiência do deambular pela cidade não se dá apenas nos personagens: o próprio narrador, "narrador-malandro" (Durigan, 1983, p. 217), estiliza sua linguagem a ponto de se identificar ao personagem narrado, o que parece reafirmar a experiência do narrador enquanto flâneur-andejo. Como bem notou Antonio Candido, em sua leitura de Malagueta, Perus e Bacanaço, a estilização da linguagem, ou mesmo a criação de uma nova linguagem literária a partir da falada no dia a dia, com as implicações sintáticas, rítmicas, vocabulares que isso acarreta, funciona como uma maneira de "diminuir as distâncias" entre o narrador e o personagem (Candido, 1999, p. 87). Essa, ainda, é uma constante de toda a obra de João Antônio, na qual o estilo jornalístico, com olhos de cronista, se conjuga ao falar popular, ultrapassando o tom meramente documental. A postura do narrador, assim, emula e simpatiza com os personagens retratados, numa verdadeira colagem entre $o$ ponto de vista e o mundo representado.

Em outro texto, espécie de conto-confissão do processo de aprendizagem do narrador, chamado "Paulo Melado do Chapéu Mangueira Serralha", essa aprendizagem pelo corpo-a-corpo com a cidade e com seus tipos marginais parece mais evidente. $\mathrm{O}$ aprendizado vem desde a infância em São Paulo, quando diz que

[corremos], eu e papai, as rodas [de choro] de Presidente Altino, Osasco, Vila Leopoldina, Lapa e nos trens caxinguentos e estropiados da Sorocabana viajamos a Jandira e Itapevi. Ou tocamos para o outro lado da cidade, para a Luz e para Santana. Reviramos os bairros, os dois nos damos as mãos nas travessias das ruas, andejos (Antônio, 1982, p. 93).

Ainda: "[se] a rua é a escola, o botequim é a universidade" (Antônio, 1982, p. 103). O estilo do narrador, o saber sobre o povo representado em sua literatura, portanto, advém, tomando esse conto como o relato da formação do narrador, do próprio contato com a cidade e seus tipos. Entre os contos, que perfazem a maior parte de sua obra literária, a representação acurada do marginal, do povo, da ralé, encontra ressonância e respeito na própria linguagem do narrador que emula estilisticamente a fala popular, além, evidentemente, de possibilitar o desenho da paisagem urbana em suas obras, que parece localizar narrador e personagens no mesmo espaço.

Essa identidade entre a linguagem do narrador e os tipos representados parece encontrar, ainda, apoio no estilo de repetições encontrados entre os contos. Expressões, colhidas in loco, são repetidas em vários dos escritos do autor, uma constante estilística que denota uma preocupação com a expressão veraz do mundo marginal representa- 
do. Ainda, cabe lembrar aspecto já relatado por outros estudos sobre a obra de João Antônio (cf. Arêas, 1999; Lucas, 1999; Lacerda, 2001, 2012; e Peres, 2011): muitas expressões, episódios, pensamentos eram anotados pelo autor sistematicamente em versos de maços de cigarro, guardanapos de botequim ou qualquer tipo de papel à mão. Jesus Antônio Durigan fala sobre o processo de "montagem" - ou bricolage - como traço estilístico de João Antônio:

A competência que garante a sobrevivência do narrador está intimamente ligada à sua capacidade de valer-se de textos (ditos populares, biografias, gírias, estereótipos etc.) e de características textuais (ritmo, pontuação, sonoridade) alheias. Sua sobrevivência como narrador depende, em outras palavras, do que não cria, mas do que agarra do mundo e dos outros e maneja com a maestria gerada pela necessidade de sobrevivência. $O$ processo criativo do narrador malandro resulta e só pode ser verificado a partir da sua capacidade de montar, do trabalho de compor um todo harmônico com partes heterogêneas e resíduos descontextualizados (Durigan, 1989, p. 16).

Considerando os limites deste artigo quanto ao aprofundamento do processo criativo do escritor, por ora pode-se dizer que muito do trabalho com o material documental revela uma espécie de preocupação jornalística, ou ainda um tipo de relação com o espaço geográfico e social concreto, que poderia recordar o processo criativo de um escritor como Émile Zola (Josephson, 1958, p. 170), caso a identificação com o universo a ser retratado não fosse tão mais evidente quanto necessária em João Antônio. Esse fato, a maior proximidade entre narrador e matéria narrada nos textos de João Antônio, não deixa de filiar o autor à tradição estilística de Zola, tal como notado por Antonio Candido (1999, p. 87). Desse modo, aparecem frases, dichotes, expressões populares, que permitiriam aferir que a disposição documental revela mais um cuidado com a representação dos personagens em foco - por meio não apenas de sua fala mas também da própria sintaxe e vocabulário do narrador - que com os espaços. A representação destes, no entanto, se se pode sugerir pelo suporte da documentação realizada pelo autor como tipicamente relacionado ao tipo de vida que pretende retratar - os versos de maços de cigarro, os guardanapos, bilhetes de loteria etc. -, parece residir num certo tipo de vivência, ao qual o próprio autor faz menção: ${ }^{6}$

\footnotetext{
${ }^{6}$ Visitamos o Acervo João Antônio no Centro de Documentação e Apoio à Pesquisa (CEDAP), da Unesp de Assis. Neste, conferimos as afirmações da crítica sobre a documentação realizada pelo autor como forma de preparação para seus escritos. Algumas vezes, certas frases anotadas direcionavam-se a textos específicos; outras, anotadas sem referência ao texto de destino. Agradecemos, principalmente, a Carol Monteiro pelo apoio e atenção dedicados à nossa consulta ao acervo do escritor.
} 
Dizem, pelo menos os que me viram viver lá fora, Lisboa, Amsterdam ou Berlim, que tenho o poder de incorporar as cidades à minha vida. O que escrevo, para ser convincente para mim, tem de trazer esse tom, essa carne, esse nervo exposto. Se não tiver essa força interior não me convencerá. Não convencendo a mim, a quem irá convencer?

Os lugares têm alma. Nem só por eles mesmos mas pela alma intrometida e inseparável que têm (Antônio apud Severiano, 2005, p. 251-252).

Narrador-andejo e experiência prática da cidade parecem indissociáveis no caso da literatura de João Antônio. Entretanto, os espaços têm sua dose de realismo ao mesmo tempo em que convivem em uma constelação à maneira alegórica, um microcosmo de um tipo de problema socioeconômico que concerne ao narrador. A preferência do autor pela descrição dos espaços degradados, em consonância com a marginalidade representada, parece apontar para um tipo de postura crítica, na qual a "negatividade" da representação fica à mostra, numa contraposição clara à apologia conservadora dos tempos de ufanismo fundados no desenvolvimento brasileiro da década de 1970 (Ribeiro, 2007, p. 33).

Em um ensaio, espécie de manifesto, petição de princípios de sua literatura, chamado "Corpo-a-corpo com a vida", publicado em Malhação do Judas carioca, João Antônio expõe seus princípios de criação literária, ressaltando notavelmente a relação direta que manifesta com o universo representado. O texto rebate os "ismos", a preocupação com a forma, típica, segundo o autor, de um escritor de costas voltadas a "certas faixas da vida deste país" e consumidor "classe média" - "gasta mais do que consome, consome mais do que assimila, assimila menos do que necessita" - de uma cultura "precariamente importada e pior ainda absorvida" (Antônio, 1975b, p. 143). ${ }^{7}$ Desse modo, João Antônio nota a distância social do escritor em relação à massa populacional do país e seus espaços, entendido previamente como locus de desigualdade e pobreza, mas de uma vitalidade admirável, que demanda necessária atenção pelo escritor.

\footnotetext{
7 Em “Abraçado ao meu rancor", texto publicado em livro homônimo de 1986, o narrador fala com amargura do escritor que "se mete a também jornalista", tipo ideal, enquanto "coisa no sistema", de um indivíduo classe média sob a armadilha do mercado (Antônio, 1986, p. 91-92). E remata: "Desaprendi a pobreza dos pobres e dos merdunchos. E, já creio, aprendi a pobreza envergonhada da classe média (p. 102). A ironia sobre o próprio programa esboçado anos antes parece contar muito da posição do escritor interessado nas questões sociais na década de 1970, um misto de necessidade honesta de representação da realidade e um atrelamento às amarras do mercado que despreza. Para uma discussão da relação entre a postura "política" de representação do povo por João Antônio e sua relação com o mercado editorial, ver Gonçalves e Hollanda (1980, p. 50-53).
} 
O que carecemos, em essência, é o levantamento de realidades brasileiras, vistas de dentro para fora. Necessidade de que assumamos o compromisso com o fato de escrever sem nos distanciarmos do povo e da terra. O que é diferente de publicar livros, e muito. Daí saltarem dois flagrantes vergonhosos - o nosso distanciamento de uma literatura que reflita a vida brasileira, o futebol, a umbanda, a vida operária e fabril, o êxodo rural, a habitação, a saúde, a vida policial, aquela faixa toda a que talvez se possa chamar radiografias brasileiras. E é devido a tal carência que, de um lado, não temos conteúdo, e de outro, nem temos forma brasileira. Pois que, a forma, resulta de uma posição intelectualizada e fornece uma falsa estética, importada, empostada, mal adquirida, sujeita a todas as ondas e sempre mal digerida (Antônio, 1975b, p. 144).

Vê-se, pois, que o autor equaliza uma posição social superior a uma espécie de consumo sem direção de estéticas importadas, manifestando um afastamento do escritor local, nacional, das formas de vida brasileiras. Para além da clara continuidade da preocupação com os aspectos nacionais, de longa data em nossa literatura - e, de resto, bastante comum em sociedades de modernização incompleta e desigual -, o autor nota a necessidade de filiação a notas culturais locais, que reflitam o viver do povo em sua luta diária. O problema formal, nesse sentido, é deslocado de filiações diretas aos "ismos", para ser centrado no próprio embate com a realidade cotidiana do país; a "forma brasileira" adviria, pois, de uma posição específica do escritor em relação a seu material, uma forma brasileira engendrada a partir do desvelar "corpo-a-corpo" da realidade representada, considerando conteúdo e forma em emergência conjunta. Cláudio Rodrigues Coração nota que a postura antiacademicista de João Antônio, além de se referir a uma postura de "entrega às esferas sociais marginalizadas", constitui uma "união do ato literário com o jornalístico na prática da escrita comprometida e imersa socialmente" (Coração, 2009, p. 23), o que referenda sua identificação, citada no ensaio de 1975, com a literatura de Lima Barreto, Graciliano Ramos, José Lins do Rego, Oswald de Andrade e Manuel Antônio de Almeida, interessados menos no brilho estilístico que no "compromisso sério com o fato social” (Antônio, 1975b, p. 144). Narração literária, texto jornalístico e experiência factual parecem, então, constituir-se em uma confluência, que denota uma postura afeita ao trato com os dados da experiência e de exposição das realidades nacionais ocultas, um "corpo-a-corpo com a vida brasileira" (Antônio, 1975b, p. 146). Narrador-andejo, narrador-repórter, cronista, a literatura de João Antônio se revela como possuidora de uma formulação híbrida, o que se verá claramente representado em Ô, Copacabana!, livro central para a delimitação dessa marca pessoal joãoantoniana. 


\section{Copacabana: "eu te bato porque eu te amo"}

Ô, Copacabana! é uma típica produção de João Antônio. Mescla de trechos narrativos, crônica e reportagem, a obra parece não se fechar rigidamente dentro de um gênero definido. Em uma nota final a uma coletânea de contos de João Antônio, Patuléia, Ô, Copacabana! é chamada de "ensaio" (Antônio, 1996a, p. 119), assim como seu livro, publicado na série Literatura comentada, sobre Noel Rosa (Antônio, 1988). Afora qualquer classificação que o texto receba, não é possível separar os gêneros presentes na obra, pois, a cada trecho, ou a cada focalização dos diversos aspectos de Copacabana, evocando uma caminhada pelo bairro e sua história, os gêneros se misturam.

Sobre Mariazinha Tiro-a-Esmo ou Elzinha Prejudicada, personagens "pingentes" do bairro, o tom narrativo tipicamente joãoantoniano toma a frente; sobre os eventos, tais como o Festival do Osso - um evento sobre cães promovido pela elite carioca - ou o réveillon "chué" do bairro, a crônica aparece com maior vigor; na caracterização da praça Serzedelo Correia, ou "praça dos Paraíbas", na descrição da vida noturna e diurna na Galeria Alaska, por sua vez, a reportagem parece ditar o tom. O que parece conferir unidade a tal mescla, sem que se perca a unidade da obra, é o foco enviesado dirigido a Copacabana, uma caracterização que ressalta as questões geralmente não consideradas para a formação da imagem do bairro carioca. Desse modo, João Antônio dá seguimento a sua marca enquanto narrador-repórter: a preferência pela "margem excluída do espaço citadino" (Ornellas, 2011, p. 75).

Nesse sentido, pode-se dizer que a representação do bairro se dá de uma maneira dúplice: o foco está todo nos seus aspectos decadentes, porém, estes não são descritos senão com referência constante à imagem de Copacabana cara aos entusiastas do turismo e da identidade nacional ufanista. Ainda quando esta Copacabana do glamour não é relatada, o que ocorre mais frequentemente, sua imagem aparece sempre como oposição necessária à descrita, isto é, ainda que o narrador-repórter prefira os bas-fonds do bairro, é impossível não relacionar essa imagem decadente e contraditória com a outra, sobejamente conhecida pelos panfletos, músicas, milhares de imagens etc.. Dois trechos da obra nos permitem situar melhor essa reflexão:

Copacabana mito, a máscara jamais caiu de todo. População grande e cosmopolita, princesinha do mar, esgoto, cloaca, classe média decadente metida a besta, vale tudo, bairro independente, hong-kong, cabocla, selva, mais um filhinho de dez anos batendo na mamãe, bairro escroto e mijado de cachorros, gueto enfiado na Zona Sul, prensado entre o morro e o mar. Muda todos os dias, paraíso do anonimato e do provisoriado. Mas a máscara não caiu. E Copa se engana, amar- 
rota, afana, apronta, estupora. Vai seduzindo e pungando turistas, iludindo otários, colhendo desavisados, cobrando alto, fintando estrangeiros, brasileiros e cariocas (Antônio, 2001, p. 80).

Fama não confere. A Copacabana que mais esculhambam é a noturna. E essa não é a mais achincalhável.

Há uma Copa não folclorizada e que sai do feixe de afobações, especulações e gulas e acaba como imagem descarnada de nossas aflições pelo desenvolvimento e progresso. Ou daquilo que chamamos assim. Teria sido certo crescer tanto em pouco mais de setenta anos? (Antônio, 2001, p. 114-115).

A imagem trabalhada de Copacabana, aqui, portanto, vira do avesso a imagem solidificada de um bairro turístico, ilustrado e reverenciado por motivos que, como se vê, só os possui se imersos em uma contradição gritante, escancaradora dos desníveis do desenvolvimento brasileiro. Assim, no bairro, a imagem valorizada serve, sobretudo, a efeitos de propaganda e, ainda, claramente, à especulação imobiliária e a um tipo de atração de grupos sociais diversos, seduzidos por sua paisagem, descoberta agora falsa e caricatural. Esta representação, em marca negativa, parece querer desvelar duas Copacabanas: a decadente caracterizando de maneira reflexa a "glamourizada" princesinha do mar. Há uma espécie, portanto, de "semântica da cidade" em João Antônio, localizada nos espaços não convencionais, ou, nas palavras de Fábio Lucas, "nos pontos em que as convenções tendem a romper-se", caracterizando "um ataque à compostura, ao bom-tom e ao decoro burgueses" (Lucas, 1999, p. 95). Ô, Copacabana! segue essa trilha, a qual, de resto, é constante em sua produção literária.

Ao bairro não afluem apenas turistas, mas moradores da Zona Norte ou da Baixada Fluminense, essa região do Rio de Janeiro onde, diz ironicamente o narrador, vivem "só setenta e cinco por cento da população carioca [...], miseravelmente" (Antônio, 2001, p. 37). Afirma, ainda, configurando a atração maciça de pessoas de variada origem, afora os turistas, imigrantes: "[Bairro] eclético, o nosso. Há pedintes de todas as idades, nacionalidades e faixas sociais" (p. 35). Um dos espaços urbanos para onde afluem esses imigrantes é a chamada praça dos Paraíbas, nome popular atribuído à praça Serzedelo Correia. O narrador cita a história da praça:

A Serzedelo passou à praça dos Paraíbas. Ou praça dos Paus-de-Arara, por causa dos pingentes urbanos nordestinos, que tangidos pela fome e pela falta de condições de vida, juntam-se aos sábados e domingos no pequeno espaço de território democrático dentro de Copa (Antônio, 2001, p. 65). 
Esses imigrantes, em relação com os espaços urbanos que adotam, por si só, valeriam como símbolo de uma imagem dúplice, típica do subdesenvolvimento brasileiro. Expulsos das regiões rurais, seja pelas condições adversas à permanência ligadas à seca ou à disputa por terras, são atraídos pelas grandes metrópoles, centros dinâmicos da economia que, não obstante, não são capazes de absorvê-los. Assim se dá o que o sociólogo Luiz Pereira chama de "urbanização sociopática", isto é, a incapacidade de as cidades corresponderem às necessidades de consumo advindas de uma nova cultura urbana que atrai imigrantes e necessita, por isso, de maior quantia de valor para suprir suas necessidades (Pereira, 1969, p. 72-76). Isso quer dizer que a atração decorrente da urbanização e de as cidades representarem frente a outras regiões, de economia deprimida, um polo mais dinâmico que poderia absorver essa mão de obra extra não encontra ressonância no crescimento das oportunidades de emprego; em outras palavras, como diz claramente Jorge Wilheim, "a cidade [em um país subdesenvolvido] adquire grande vitalidade e elevada taxa de crescimento antes e independentemente de qualquer industrialização de porte" (Wilheim, 1969, p. 27). Assim, a cidade subdesenvolvida, ao contrário das cidades modernas tipicamente europeias ou norte-americanas, que cresceram acompanhando o avanço acelerado da indústria - o que não quer dizer que não tivessem também suas contradições próprias -, não é capaz de absorver toda a população que a ela aflui em ritmo desordenado, dada a própria divergência de dinâmicas na economia como um todo. Se a economia rural sofre problemas ou propaga fatores que expulsam a mão de obra, esta, já mais ou menos integrada a padrões urbanos de consumo e uma cultura urbana difundida pelos meios de comunicação, aflui à cidade e, de um modo ou de outro, acaba à margem (Wilheim, 1969, p. 32).

A praça, enquanto espaço urbano, aparentemente, em sua vivência "democrática", como diz o narrador, funciona como ponto de refúgio de uma comunidade desenraizada, que não consegue encontrar os meios de viver na cidade: são "pingentes urbanos". Pingentes, para João Antônio, são não apenas os passageiros que se arriscam dependurados às portas dos trens em movimento, como caracteriza em um texto sobre os usuários da linha de trem da Central do Brasil - "Pingentes" (Antônio, 1975b, p. 24-29; 1996b, p. 43-49):

Mais do que pobres, os passageiros da Central do Brasil parecem não apenas pingentes nos trens, mas pingentes da cidade, uma espécie, em quantidade e qualidade, de sobreviventes urbanos, sempre pendurados na cidade e nunca fixos, estabilizados ou tranquilos (Antônio, 1975b, p. 25). 
Esses "pingentes", portanto, além de fazerem parte da constelação pessoal de tipos na literatura de nosso autor, são uma espécie de grupo social depauperado, para o qual a representação se volta, conjugando espaço e vivência dos personagens. Dada a história dos retirantes que o texto resgata, o narrador compõe uma descrição sobejamente adequada da relação estabelecida por esses indivíduos com o espaço urbano, evocando não apenas um problema específico do bairro mas um problema nacional por excelência.

A caracterização da praça, no entanto, não se completa com os pingentes urbanos. A seleção do que descreve, sobretudo os arredores da praça e seus frequentadores, mostra uma característica interessante dos textos de João Antônio: diferentemente da notação naturalista, a ênfase no espaço é deslocada para uma caracterização mais detida do personagem que nele atua. Mais que um personagem que reflete seu "meio", portanto, um espaço que se descortina a partir da prática do indivíduo. Talvez aí esteja o sentido das palavras de Bosi, em prefácio a Abraçado ao meu rancor, quando afirma que João Antônio, ao representar o povo, não o deixa "se transformar em massa" (Bosi, 1986, p. 13). A ênfase está nos tipos, não no que os circunda, o que não diminui a importância do espaço, mas o interpreta como dimensão indissociável do grupo social que o utiliza e representa:

Na praça dos Paraíbas fervem, enquanto o progresso não vem, botecos xexelentos, de uma portinha só. Apertados, abafados, fedidos, do tipo engasga-gato para receber vizinhando o desemprego, o lúmpen, o provisoriado. O zero (Antônio, 2001, p. 69).

A cadeia final desse tipo de representação está nos moradores de rua, sempre presentes na descrição do narrador em Ô, Copacabana!. Falando sobre a falta de motivos para comemorar, nos botequins do bairro carioca outro espaço de convivência "democrática" da cidade -, o narrador ironiza: [Brindamos], quem sabe, o fato de encontrarmos, à soleira do nosso edifício, nas madrugadas, quando nos recolhemos tarde, mais uma turminha sebenta de três, quatro garotos menores de dez anos, dormitando, encolhidos, caquerados, sujos, embrulhados ou não em folhas de jornal. Pedimos passagem aos miseráveis, abrimos a porta e entramos em nossa casa (Antônio, 2001, p. 49).

Não estamos nem aí. Pedimos passagem aos mendigos e vamos tocando. Que temos a praia e o botequim (Antônio, 2001, p. 50).

São espaços urbanos apropriados pelos "pingentes urbanos" como forma mesmo de ocupação de um local que é de todos, embora não sejam eles, obviamente, contemplados pela imagem oficial do bairro. O desprezo irônico do narrador sobre os "pingentes urbanos" nada mais é que a re- 
presentação cínica, semelhante, pois, à própria imagem cínica do progresso brasileiro e da autoimagem ufanista, ligada ao bairro e referendada pelas elites e pelos poderes do Estado e do mercado. Note-se que essa representação entre cínica e irônica reaparece, sobretudo quando o narrador quer tratar da vida dos socialmente integrados - ou supostamente integrados - no bairro da Zona Sul. O jogo narrativo entre uma representação irônica sobre os agentes, ações ou espaços da elite e a representação crua da desigualdade do bairro é uma constante na obra, e cria um efeito crítico deveras efetivo, sobretudo quando consideramos que a voz narrativa, entre literária e jornalística, faz as vezes de uma crônica de costumes que vai encontrar suas raízes nos antigos escritos de Machado de Assis para a imprensa. Aliás, João Antônio cita o Machado de Assis das crônicas em um trecho que certamente vale para seu interesse frente às desigualdades estapafúrdias brasileiras: " $\mathrm{O}$ país real, esse é bom, o povo revela os melhores instintos; mas o país oficial, esse é caricato e burlesco" (Assis apud Antônio, 1996b, p. 59). O próprio João Antônio, em entrevista, põe à baila seu interesse aguçado pela desigualdade abissal brasileira, em suas multivariadas facetas:

Zona Franca e devastações na Amazônia e a maior cooperativa de trabalhadores da América do Sul entre os triticultores de Ijuí, no extremo Sul, a cento e poucos quilômetros da fronteira com a Argentina. Ponte Rio-Niterói e quase três milhões de favelados no Rio de Janeiro. Três colheitas de feijão ao ano e o país ameaçado com uma economia de guerra. Sem lastro habitacional para o povo, o Rio de Janeiro tem, no entanto, uma classe média alta que mora pagando o condomínio mais caro do mundo: Ipanema-Leblon. O discreto charme buñuelesco é nada diante das festivalanças e desperdícios do Baixo-Leblon ou da Gávea Pequena. Bóias-frias e limousines importados (Antônio apud Gonçalves e Hollanda, 1980).

Desse modo, aparentemente, o próprio movimento narrativo em $\hat{O}$, Copacabana! parece referendar as desigualdades representadas. O interesse de João Antônio por essas dualidades -“escassez e sobejo" (Antônio, 1996b, p. 72) - da vida brasileira encontra, nesse traço de estilo, uma forma de indicar a intervenção subjetiva, para além da mera descrição jornalística, da qual nosso narrador se afasta claramente.

Esse movimento, entre o documento mais ou menos agressivo de nossa miséria e a ironia não complacente com as elites, constitui muito do tom de Ô, Copacabana!. O próprio bairro, objeto do texto, parece representar um microcosmo de um tipo de desenvolvimento à moda brasileira, o qual, segundo Flávio Aguiar (1999), citando um trecho de Antônio Candido na apresentação a Dedo-duro, expressa a "normalidade do socialmente anormal" (Candido apud Aguiar, 1999, p. 113). Não 
raramente em sua obra, João Antônio refere-se ao chamado "progresso" de maneira depreciativa, intentando representar a particularidade da mudança socioeconômica brasileira; em $\hat{O}$, Copacabana!, o narrador afirma que o bairro representa uma "imagem descarnada de nossas aflições pelo desenvolvimento e progresso. Ou daquilo que chamamos assim" (Antônio, 2001, p. 115, grifo nosso). O estilo entre o irônico e o documental cru sugere uma posição cética em relação a esse progresso que mantém em pé o conhecido quadro de miséria, referendado aqui pela convivência promíscua entre a barbárie e a civilização presentes nessa imagem construída do bairro do Rio de Janeiro.

Para os minimamente integrados no quadro social, sobram a especulação imobiliária e a expulsão para bairros cada vez mais distantes do centro e dos bairros de prestígio. Walter Benjamin cita, entre as notas e materiais das Passagens, um trecho de Lefeuve que dá conta justamente desta dinâmica da cidade moderna: "[Enquanto] a rua ainda é relativamente nova, ela pertence à gente humilde, e desvencilha-se desta quando a moda lhe sorri" (Benjamin, 2009, p. 123). Sobre a especulação imobiliária em Copacabana, nosso narrador diz que "[habitar], aqui é, pois, um luxo" (Antônio, 2001, p. 27). Fala, assim, ironicamente, da "civilização do quarto-e-sala" (p. 30), moradores de prédios de apartamentos minúsculos, surgidos em locais onde a valorização fundiária é tremenda. Ainda:

De uma ponta a outra, nosso bairro é feito um paliteiro. Vivemos uma rotina do espeto, num paliteiro de prédios e apartamentos.

Haverá pouca invenção moderna, porca e aviltante, que separe um homem de seu semelhante como um prédio desses. Na favela, até lá, sobrevive algum espírito comunitário, vizinho vê a cara do vizinho. Quando em quando, se reza o verbo amar e, volta e meia, a palavra mutirão comparece. Tanto que é o lugar onde mais se canta no Rio de Janeiro. Razão haverá, apesar do miserê (Antônio, 2001, p. 47).

Esse trecho é deveras importante, em vários sentidos. Primeiramente, porque a construção de prédios, nessa "civilização do quarto-e-sala", acompanhando a valorização fundiária e a especulação, reforça o destino individualista, sempre notado na vida sob o capitalismo, especialmente nas grandes cidades - à guisa de comparação, a atitude blasé, típica do indivíduo na metrópole, notada por Georg Simmel, é apenas uma de suas manifestações (Simmel, 1979, p. 15-18). Por outro lado, a expulsão dos pobres é um dos fermentos para a edificação de favelas, locais de tensão social, mas, também, de uma vida comunitária um tanto mais integrada que nos bairros valorizados. Cabe notar, ainda, que esse tipo de expulsão dos pobres para os subúrbios, fomentando a edificação de favelas, vem de 
longa data no Rio de Janeiro. As reformas do prefeito Pereira Passos, por exemplo, seguindo uma atitude de embelezamento e de planejamento de uma cidade feita à imagem e à semelhança do que as elites a ela queriam impingir, identificadas que almejavam estar ao modelo europeu, deslocaram os pobres para longe do centro, com a demolição de cortiços, a valorização fundiária etc. (Ribeiro, 2001, p. 141).

Tivemos, portanto, manifestações de Haussmann nos trópicos; aqui, o intuito do "artista demolidor" (Benjamin, 2009, p. 128) não era o alargamento de vias para evitar barricadas ou facilitar a tática militar, embora o desprezo pelas massas seja quase idêntico: no Rio de Janeiro, foi, utilizando como álibi a identificação ideológica entre classes populares e classes perigosas - algo muito nosso, muito brasileiro, já de longa data, como se vê -, ou ainda, o da sanitarização da cidade, a expulsão mesma dos pobres para a edificação de uma cidade voltada para a imagem, para a identificação com a modernização capitalista, tal qual valorizada pelo tempo (Chalhoub, 1996, p. 170-176). Note-se, aliás, que a crítica à adoção de padrões culturais urbanos estrangeiros é notada pelo narrador em Ô, Copacabana!. Ornellas afirma que "o resgate do passado histórico-cultural", sempre presente nas obras de João Antônio, se dá geralmente no contexto de referências críticas "à adoção de padrões culturais estrangeiros" (Ornellas, 2011, p. 77), entre os quais a modernização do bairro, sob o viés da especulação imobiliária. Comentando a oposição entre os jovens supostamente integrados à vida moderna estrangeirada, e os idosos que caracterizam parte da vida do bairro, o narrador afirma: "Estamos, dizem [os antigos], sendo pasteurizados, condicionados por maus hábitos adquiridos por importação. Bebemos, comemos e fumamos o que não deveríamos" (Antônio, 2001, p. 104).

O trecho em questão, por fim, coloca em oposição a representação de um espaço "da ordem", um bairro impulsionado economicamente pela especulação imobiliária, e a representação dos marginais no desenvolvimento encontrado na metrópole. A descrição, porém, que identifica a favela como um espaço comunitário, em oposição à civilização individualista, encontra-se em um contraste revelador, que indica novamente a simpatia do narrador pelas classes populares, pelo "país real", por assim dizer. Note-se que essa postura é encontrada em outras obras do autor, tais como o texto em que, à maneira da crônica, retoma a região de São Paulo onde o autor passara a infância, o Morro da Geada:

Nenhum de nós sabia dizer a palavra solidariedade. Mas na casa de outro tio, o nosso tio Otacílio, criavam-se até filhos dos outros e estou certo que o nosso coração era simples, espichado e melhor. Não desandávamos a reclamar da vida, não nos hostilizávamos fei- 
to possessos, tocávamos a pé para baixo e pra cima e quando um se encontrava com o outro, a gente não dizia: 'oi'. A gente se salvava, largo e profundo:

- Ô, batuta! (Antônio, 1991, p. 11-13).

Desse modo, pode-se dizer que aquele estilo dicotômico, que opõe a ironia à descrição crua das contradições brasileiras, se desdobra numa constante temática, a qual já havíamos notado como característica essencial do narrador na obra de João Antônio: a descrição das classes populares, ainda quando intenta realizar uma representação a mais fiel possível à sua situação, tende para uma visão mais ou menos idílica, quase rural, do tipo de convivência encontrado nos bairros populares. Esse aspecto, além de bem representar uma dinâmica social de interesse - a manutenção de padrões culturais rurais em plena urbe - indica uma constante na obra de João Antônio, a de dosar seu "realismo feroz" - para falar com Antonio Candido (2006, p. 255) - com traços de simpatia e solidariedade em relação às classes subalternas, o que o afasta, de certo modo, das representações literárias mais atuais do submundo urbano (Lacerda, 2012, p. 39). Estas, tal como afirma Wander Melo Miranda sobre a "literatura marginal" - ou "periférica", de modo a não ser confundida com a poesia homônima da década de 1970 -, estão presentes em textos "que optam por um brutalismo temático e formal", como nos romances de Ferréz, por exemplo (Miranda, 2011, p. 208). Evidentemente, não se deve deixar de notar certa linha de continuidade entre João Antônio e a literatura produzida hoje, mas a diferença de tom é notável, o que daria a pensar sobre as mudanças ocorridas nas condições de produção da literatura contemporânea. Um dos fatores de continuidade se dá na recusa da linguagem das elites para a representação da cidade, fato expresso na construção formal dessas obras, afeitas a uma relação direta com a visão de mundo das classes subalternas.

A imagem das elites sobre a cidade é, justamente, o que João Antônio procura desconstruir. Sua abordagem do espaço urbano volta-se toda para os "pingentes urbanos", os "merdunchos", os marginalizados, relegando para as elites apenas o rótulo, que o narrador faz crer ser plenamente justificável, de "babaquara" (Antônio, 2001, p. 97). O embate entre uma imagem oficial de Copacabana, sustentada pela propaganda, pelo Estado e pelas classes médias, e o bairro real, contraditório, problemático, parece ser a mola principal do movimento do texto. Não obstante esse desmascaramento, não é pela falta de apreço pelo bairro que isso se dá. Sempre com humor, João Antônio diz, nos trechos finais da obra: 
Se entendido com humildade, o bairro escroto continua muito amado. Mais, é claro, pelos que não têm outro, os eira-sem-beira, os pés-inchados, os zés-manés, os paus-de-arara, as marias-judias, a candangagem que nem nasceu aqui. Empurrou-se para cá por não ter para onde ir, despencou-se sem saber onde e já perdeu as origens. Nesses, então, gostar de Copacabana é até uma dignidade. [...]

Apesar da patifaria e da devastação, da exploração e do aviltamento, do terror das denúncias vazias, do caos ganhando da gente, da pouca-vergonha, ainda não nos mataram o amor (Antônio, 2001, p. 117-118).

A representação de João Antônio, dessa maneira, nos parece retratar com maior empatia o bairro e os espaços urbanos quando justamente diz da verdade das classes pauperizadas, apresentando, em oposição, até mesmo revolta, a seus problemas quando vistos sob a ótica oficial: "no bairro, como na nossa cidade, só cantamos as glórias. Do fiasco, ninguém fala. [...] Êta joguinho larápio da omissão e do ufanismo!" (Antônio, 2001, p. 107). Nesse sentido, é perfeitamente mais compreensível e estimulante essa visão do bairro, submetida que está não às aparências da apologia estatal e da propaganda turística, mas ancorada numa experiência que se quer notada em seu embate direto com a realidade, identificado, enraizado numa inspiração popular, refletida na própria escrita.

\section{Referências}

AGUIAR, Flávio (1999). Evocação de João Antônio ou do purgatório ao inferno. Remate de Males, Campinas, n. 19, p. 105-120.

ANTÔNIO, João (1975a). Malagueta, Perus e Bacanaço. 2. ed. Rio de Janeiro: Civilização Brasileira; Brasília: INL.

(1975b). Malhação do Judas Carioca. Rio de Janeiro: Civilização Brasileira.

(1976). Casa de loucos. Rio de Janeiro: Civilização Brasileira.

(1982). Dedo-duro. 2. ed. Rio de Janeiro: Record.

(1986). Abraçado ao meu rancor. Rio de Janeiro: Guanabara.

(1988). Noel Rosa. 2. ed. São Paulo: Nova Cultural.

(1991). Zicartola e que tudo mais vá para o inferno! São Paulo: Scipione.

(1996a). Patuléia: gentes da rua. São Paulo: Ática.

(1996b). Dama do encantado. São Paulo: Nova Alexandria.

(2001). Ô, Copacabana! São Paulo: Cosac Naify.

ARAGON, Louis (1996). O camponês de Paris. Rio de Janeiro: Imago.

ARÊAS, Vilma (1999). Chorinhos de um retratista (improviso). Remate de Males, Campinas, n. 19, p. 121-137. 
BENJAMIN, Walter (1989). Charles Baudelaire: um lírico no auge do capitalismo. In: Obras escolhidas III. São Paulo: Brasiliense.

(2009). Passagens. Belo Horizonte: Editora UFMG; São Paulo: Imprensa Oficial do Estado de São Paulo.

BOSI, Alfredo (1986). Um boêmio entre duas cidades. In: ANTÔNIO, João. Abraçado ao meu rancor. Rio de Janeiro: Guanabara.

CANDIDO, Antônio (1999). Na noite enxovalhada. Remate de Males, Campinas, n. 19, p. $83-88$.

(2006). A nova narrativa In: A educação pela noite. 5. ed. Rio de Janeiro: Ouro sobre Azul.

CHALHOUB, Sidney (1996). Cidade febril: cortiços e epidemias na corte imperial. São Paulo: Companhia das Letras.

CORAÇÃO, Cláudio Rodrigues (2009). Repórter-cronista: jornalismo e literatura na interface de João Antônio com Lima Barreto. Dissertação (Mestrado em Comunicação) - Universidade Estadual Paulista "Júlio de Mesquita Filho", Bauru.

DURIGAN, Jesus Antônio (1983). João Antônio e a ciranda da malandragem. In: SCHWARZ, Roberto (Org.). Os pobres na literatura brasileira. São Paulo: Brasiliense. (1989). João Antônio: o leão e a estrela. In: ANTÔNIO, João. Leão-de-chácara. 7. ed. São Paulo: Estação Liberdade

GONÇALVES, Marcos Augusto; HOLLANDA, Heloísa Buarque de (1980). Política e literatura: a ficção da realidade brasileira. In: GONÇALVES, Marcos Augusto; HOLLANDA, Heloísa Buarque de; FREITAS FILHO, Armando (Orgs.). Anos 70: Literatura. Rio de Janeiro: Europa.

JOSEPHSON, Matthew (1958). Zola e seu tempo. 2. ed. São Paulo: Companhia Editora Nacional.

LACERDA, Rodrigo (2001). De princesinha a cadela desdentada. In: ANTÔNIO, João. Ô, Copacabana! São Paulo: Cosac Naify.

(2012). Ele está de volta. In: ANTÔNIO, João. Contos reunidos. São Paulo: Cosac Naify.

LUCAS, Fábio (1999). Reflexões sobre a prosa de João Antônio. Remate de Males, Campinas, n. 19, p. 89-103.

MIRANDA, Wander Melo (2011). Ficção brasileira 2.0. In: BOTELHO, André; SCHWARCZ, Lilia Moritz (Orgs.). Agenda brasileira: temas de uma sociedade em mudança. São Paulo: Companhia das Letras.

ORNELLAS, Cláudia Ávila (2011). João Antônio, leitor de Lima Barreto. São Paulo: Edusp.

PEREIRA, Luiz (1969). Urbanização e subdesenvolvimento. In: Urbanização e subdesenvolvimento. Rio de Janeiro: Zahar.

PERES, Elena Pajaro (2011). Cantos e recantos urbanos na literatura de João Antônio. Revista de História, São Paulo, n. 164, p. 311-330. 
RIBEIRO, Joana D'Arc (2007). Vozes em ruinas: experiência urbana e narrativa curta em João Antônio e Rubem Fonseca. Tese (Doutorado em Letras) - Faculdade de Ciências e Letras de Assis, Universidade Estadual Paulista "Júlio de Mesquita Filho", Assis. RIBEIRO, Luiz César de Queiroz (2001). Transformação geofísica e explosão urbana. In: SACHS, Ignacy; WILHEIM, Jorge; PINHEIRO, P. S. (Orgs.). Brasil: um século de transformações. São Paulo: Companhia das Letras.

SEVERIANO, Mylton (2005). Paixão de João Antônio. São Paulo: Casa Amarela.

SILVA NETO, José Pereira (2002). O espaço urbano de São Paulo no realismo ficcional de João Antônio. Dissertação (Mestrado em Letras) - Faculdade de Ciências e Letras de Assis, Universidade Estadual Paulista "Júlio de Mesquita Filho", Assis.

SIMMEL, Georg (1979). A metrópole e a vida mental. In: VELHO, Otávio Guilherme (Org.). O fenômeno urbano. 4. ed. Rio de Janeiro: Zahar.

WILHEIM, Jorge (1969). Urbanismo no subdesenvolvimento. Rio de Janeiro: Saga.

Recebido em dezembro de 2012. Aprovado em abril de 2013.

\section{resumo/abstract}

\section{Percursos da cidade em João Antônio}

Júlio Cezar Bastoni da Silva

Este artigo propõe uma análise da representação da cidade na literatura de João Antônio, tendo como referência principal a obra Ô, Copacabana!, publicada em 1978. A cidade nos textos de João Antônio mostra-se constituída por uma linguagem e uma focalização próprias ao narrador que se quer identificado às classes populares, emulando o falar dos excluídos por meio de um tratamento linguístico com implicações sintáticas, rítmicas e vocabulares, que constroem uma visão de mundo à parte das representações urbanas realizadas pelas elites. Desse modo, João Antônio intenta representar a cidade a partir do foco dessas classes, o que redunda na predileção pelos espaços obscuros, à margem das imagens oficiais.

Palavras-chave: João Antônio, Ô, Copacabana!, narrativa, espaço urbano.

\section{Tours around the city in João Antônio}

Júlio Cezar Bastoni da Silva

This article proposes an analysis of the representation of the city in João Antônio's literature, having as main reference the book Ô, Copacabana!, 
published in 1978. The city in João Antônio's writings seems to be composed by the particular language and focus of the narrator, who wants himself identified to the lower classes, emulating the talk of the excluded people by a linguistic treatment, with its syntactic, rhythmic and vocabulary implications, building a point of view apart from the representations of the upper classes. Thus, João Antônio tries to represent the city through the focus of those social classes, which results in the preference for unknown places, marginal from official images.

Keywords: João Antônio, Ô, Copacabana!, narrative, urban space. 